The University of San Francisco

USF Scholarship: a digital repository @ Gleeson Library |

Geschke Center

Philosophy

College of Arts and Sciences

1992

\title{
Naturalized Philosophy of Science with a Plurality of Methods
}

David J. Stump

University of San Francisco, stumpd@usfca.edu

Follow this and additional works at: http://repository.usfca.edu/phil

Part of the Philosophy Commons

\section{Recommended Citation}

Stump, David J., "Naturalized Philosophy of Science with a Plurality of Methods" (1992). Philosophy. Paper 12.

http://repository.usfca.edu/phil/12

This Article is brought to you for free and open access by the College of Arts and Sciences at USF Scholarship: a digital repository @ Gleeson Library | Geschke Center. It has been accepted for inclusion in Philosophy by an authorized administrator of USF Scholarship: a digital repository @ Gleeson

Library | Geschke Center. For more information, please contact repository@usfca.edu. 


\title{
NATURALIZED PHILOSOPHY OF SCIENCE WITH A PLURALITY OF METHODS*
}

\author{
DAVID STUMP†‡ \\ Department of Philosophy \\ University of San Francisco
}

\begin{abstract}
Naturalism implies unity of method - an application of the methods of science to the methodology of science itself and to value theory. Epistemological naturalists have tried to find a privileged discipline to be the methodological model of philosophy of science and epistemology. However, since science itself is not unitary, the use of one science as a model amounts to a reduction and distorts the philosophy of science just as badly as traditional philosophy of science distorted science, despite the fact that the central theme of naturalized philosophy of science is that methodology should be true to science as practiced. I argue that naturalized philosophy of science must apply a plurality of methods to epistemological issues.
\end{abstract}

Ever since the overthrow of logical positivism, philosophers of science have paid close attention to the history of science and to current scientific practice, and the use of evidence from case studies can now be taken for granted as central to studies of scientific methodology. Nonfoundationalists have turned to naturalism to justify cognitive aims and the methods of science. The traditional model of science is that facts, methods and aims form a hierarchy. Methodology determines what counts as a fact and the basic aims of science determine (through philosophical analysis) what counts as proper methodology. This model leads to a kind of relativism in the views of Popper and some of the Logical Positivists since they see aims and methods as conventional. Epistemological naturalists reject the hierarchy and attempt to avoid conventionalism by claiming that scientific facts can influence the choice of methods and aims. While naturalism exists in several forms, a general formulation will be adequate for the discussion here. Traditionalists hold that methodology is an autonomous, a priori disciple, while naturalists hold that methods and cognitive aims can be informed by scientific knowledge.

*Received September 1990; revised June 1991.

†This material is based upon work supported by the National Science Foundation under a grant awarded in 1990. I thank the NSF and Stanford University for support. I have benefited from discussions on these topics with John Dupré, Peter Galison and Joseph Rouse, from discussions at Larry Laudan's NEH seminar on Naturalized Epistemology, and from the comments of an anonymous referee.

¥Send reprint requests to the author, Department of Philosophy, University of San Francisco, San Francisco, CA 94117-1080, USA.

Philosophy of Science, 59 (1992) pp. 456-460.

Copyright (c) 1992 by the Philosophy of Science Association. 
Naturalism implies unity of method-an application of the methods of science to the methodology of science itself and to value theory. Epistemological naturalists have tried to find a privileged discipline to be the methodological model for epistemology, generally some version of psychology - behaviorist for Quine (1969), and cognitive for Alvin Goldman (1986). Naturalists in the philosophy of science have followed suit and attempted to reduce methodology to one metamethod. This metamethod might again be psychology, as for Ronald Giere (1988, 1989), history of science, as for Larry Laudan $(1984,1987)$, evolutionary biology, as for Donald Campbell (1974), or sociology, as in the work of Steve Fuller (1988). ${ }^{1}$

Concurrent with the development of naturalized philosophy of science, a central theme of recent philosophy of science has become the view that the methods of science themselves are not unitary. This can be seen in Dudley Shapere's (1984) argument that science has developed into independent domains; in the new philosophy of experiment advocated by Ian Hacking (1983) and Peter Galison (1987, 1988, 1989) in which experiment has a life of its own, independent of theory; in Arthur Fine's (1986) advocation of an antiessentialist view of science as a way of getting beyond debates over realism; in John Dupré's (1983) pluralistic metaphysics, and in Thomas Nickles's (1987) claim that scientists only concern themselves with domain specific methods. Indeed, in terms of institutional practice, philosophy of science has splintered into the philosophy of special sciences. One would think that naturalized philosophy of science would attempt to follow the breakup of science into domains in order to apply scientific methods to the philosophy of science, but this has not been the case.

A tension which has been ignored by the proponents of naturalized philosophy of science has been introduced into their program. On the one hand, naturalism demands unified method. On the other hand, naturalism also demands that the philosophy of science be true to science as practiced and, pace the positivists, science itself has been shown not to be unified in its method. The point of getting beyond both the positivistic and Kuhnian analyses of science is precisely to avoid the claim that there is a single matrix in which theories, methods and aims are tightly connected. Naturalized philosophers of science have not gone nearly far enough in rejecting these holistic schemes.

With all due respect to Quine (1953), I suggest that there are two dogmas of naturalized epistemology. The first is that there must be a privi-

\footnotetext{
${ }^{1}$ Here I follow James Maffie (1990, n. 8). See Maffie (1990) for an excellent survey of recent work in naturalized epistemology. As the referee pointed out, it is ironic that the disciplines which the naturalists have decided to privilege in an attempt to be scientific about philosophy are held in low esteem as sciences.
} 
leged science which will be the single model for metamethodology. The second, which I will only mention here, is acceptance of a strict fact/value distinction which makes normative claims about methodology impossible-accepting the "naturalistic fallacy" as real. Of course, the latter does not apply to all naturalists, notably Laudan. While the view that normative claims are only possible if one adopts a nonnaturalized position seems to be remarkably well entrenched; I think it is dangerously debilitating, since it leads immediately to a false dilemma. If the only avenue for grounding values and aims is a priori philosophical analysis, we must either hold onto the discredited apriorism or embrace relativism. In support of normative claims, I will only say that whatever one thinks about the status of ethical and aesthetical values, the idea that what we know cannot influence cognitive aims and values seems absurd (see Harold Brown 1988 as well as Laudan 1987, 1990 for arguments in favor of normative naturalism and references to the current literature on this topic).

Since science itself is not unitary, the attempt to privilege one scientific discipline as the method of naturalized philosophy of science has left naturalism as a form of reduction. When I say that epistemological naturalists reject the traditional hierarchical account of content, methods and aims, I take them to be committed to the view that the methods of philosophy of science are the same as those of science. While it is certainly true that we can distinguish different levels of analysis in the sense that the science of science is metalevel discourse about science rather than the object-level discourse of science, naturalism requires that the methodology of this metalevel discourse have the same status as the methodology of science. So, if there are many methods in science, then there must be many methods in philosophy of science as well.

I do not want to argue that philosophy of science must use all of the methods of the sciences, for there may be one or several methods that are more appropriate for the philosophy of science. The point is rather that any method of science could be applicable in principle to the study of science. My worry about reduction is that some possibilities are ruled out, and this will lead to a distorted view of science. There are surely many stories to tell about science, and many different aspects of science require study. I do not see how, say, cognitive psychology could tell us everything that we need to know about science, or even how one could make the weaker claim that it is fundamental. The attempt to privilege one science as a model for philosophy of science shows that the naturalists share essentialism with the traditionalists. But the assumption that there is one unified scientific method that applies everywhere has been refuted. ${ }^{2}$ Furthermore, we have been given no reason to think that only

${ }^{2}$ I have argued elsewhere (Stump 1991) that very weak methodologies which may seem to be universal are in fact too universal since they apply to nonscientific endeavors as well. 
one method will be successful in philosophy of science, and using only one method where several may apply amounts to a reduction and distorts the philosophy of science by leaving out these other methods of inquiry. If one method turned out to be particularly successful in the philosophy of science, would that not give us good reason to use that method and no other? Perhaps, but I doubt strongly whether naturalized philosophy of science is now in a position to make such claims.

To avoid misunderstanding, I should emphasize here that I am taking a critical stance on the methodology of philosophy of science. The plurality that I am advocating here is not intended to proclaim that anything goes in philosophy of science, as a naturalized Paul Feyerabend might. I reject the view that epistemology and methodology must be autonomous disciplines, and I do so on the basis of the failure of nonnaturalized accounts of science. Thus, I agree with naturalism and advocate testing methodologies for the philosophy of science much as we would test methodologies for science, and I expect that many methods in philosophy of science will turn out to be unproductive. ${ }^{3}$

The naturalistic reduction to a single discipline not only distorts the philosophy of science in the same essentialist way in which traditional philosophy of science distorted science, it also leads to irrelevant disputes. For example, a recent science studies debate between naturalized philosophy of science and socialized philosophy of science was defined as a debate between overextended positivism and the salvation of human science (Woolgar 1989, Nickels 1989). I suggest that naturalists have no need for overextending their favored disciplines. If we deny the essentialist view of science and reject calls to reduce science studies to a privileged disciple, then we do not need to worry about hegemony. Instead, cognitive science will have a role in science studies, as will the traditional humanistic disciplines.

Naturalized philosophy of science can easily resolve the tension between the demands for unity of method and for being true to science if the same plurality of method which is found in science is applied to studies of methodology and of cognitive aims. In this way, we have a unity of method, but the method itself will be interpreted pluralistically. Traditional philosophy of science has methodology autonomous and scientific method unified. Advocates of naturalized philosophy of science correctly interpret methodology as part of scientific inquiry, but they have relied too heavily on single methodologies as models and have generalized these models too far to be true to science. Besides raising problems of reduction, modeling the philosophy of science on a single science is

\footnotetext{
${ }^{3}$ In Stump (1991), I argue that nonfoundational, naturalized accounts have the resources to provide objective judgements.
} 
simply unjustified. The history of science, cognitive psychology, and social factors all constrain philosophy of science just as they constrain science itself. It is time for naturalized philosophers of science to give up their dogmas.

\section{REFERENCES}

Brown, H. I. (1988), "Normative Epistemology and Naturalized Epistemology", Inquiry 31: 53-78.

Campbell, D. T. (1974), "Evolutionary Epistemology", in P. A. Schilpp, (ed.), The Philosophy of Karl Popper, vol. 1. La Salle: Open Court, pp. 413-463.

Dupré, J. (1983), "The Disunity of Science", Mind 92: 321-346.

Fine, A. (1986), The Shaky Game: Einstein, Realism, and the Quantum Theory. Chicago: University of Chicago Press.

Fuller, S. (1988), Social Epistemology. Bloomington: Indiana University Press.

Fuller, S.; De Mey, M.; Shinn, T. and Woolgar, S. (eds.) (1989), The Cognitive Turn: Sociological and Psychological Perspectives on Science. (Sociological Sciences Yearbook, 1989) Dordrecht: Kluwer.

Galison, P. L. (1987), How Experiments End. Chicago: University of Chicago Press.

. (1988), "History, Philosophy, and the Central Metaphor", Science in Context 2: $197-212$.

_- (1989), "Multiple Constraints, Simultaneous Solutions", PSA 1988, vol. 2. East Lansing: Philosophy of Science Association, pp. 157-163.

Giere, R. N. (1988), Explaining Science: A Cognitive Approach. Chicago: University of Chicago Press.

. (1989), "The Units of Analysis in Science Studies", in Fuller et al. (eds.), pp. $3-12$.

Goldman, A. I. (1986), Epistemology and Cognition. Cambridge, MA: Harvard University Press.

Hacking, I. (1983), Representing and Intervening. Cambridge, England: Cambridge University Press.

Laudan, L. (1984), Science and Values: An Essay on the Aims of Science and Their Role in Scientific Debate. Berkeley and Los Angeles: University of California Press.

_ . (1987), "Progress or Rationality? The Prospects for Normative Naturalism", American Philosophical Quarterly 24: 19-31.

- (1990), "Normative Naturalism", Philosophy of Science 57: 44-59.

Maffie, J. (1990), "Recent Work on Naturalized Epistemology", American Philosophical Quarterly 27: 281-293.

Nickles, T. (1987), "From Natural Philosophy to Metaphilosophy of Science", in P. Achinstein and R. Kargon (eds.), Kelvin's Baltimore Lectures and Modern Theoretical Physics: Historical and Philosophical Perspectives. Cambridge, MA: MIT Press, pp. 507-541.

- (1989), "Integrating the Science Studies Disciplines", in Fuller et al. (eds.), pp. $225-256$.

Quine, W. V. (1953), "Two Dogmas of Empiricism", in From a Logical Point of View. New York: Harper \& Row, pp. 20-46.

. (1969), "Epistemology Naturalized", in Ontological Relativity and Other Essays. New York: Columbia University Press, pp. 69-90.

Shapere, D. (1984), Reason and the Search for Knowledge. Dordrecht: Reidel.

Stump, D. (1991), "Fallibilism, Naturalism and the Traditional Requirements for Knowledge", Studies in History and Philosophy of Science 22: 451-469.

Woolgar, S. (1989), "Representation, Cognition and Self: What Hope for an Integration of Psychology and Sociology?", in Fuller et al. (eds.), pp. 201-224. 